\title{
The Development Of A Guidebook For Designing Interactive Distance Learning (Pijar) For Lecturers Of Technology And Vocational Educational Departement
}

\section{Pengembangan Buku Panduan Merancang Pembelajaran Interaktif Jarak Jauh (Pijar) Bagl Dosen Jurusan Pendidikan Teknologi Dan Kejuruan}

\author{
Ratna Pancawati ${ }^{1)}$ \\ 1) Program Studi Pendidikan Teknik Mesin, Jurusan Pendidikan Teknologi dan Kejuruan \\ Universitas Palangka Raya, Kampus UPR Tunjung Nyaho Jl. H. Timang, 73111A \\ e-mail: ratna.pancawati@fkip.upr.ac.id
}

\begin{abstract}
The research aims at developing a guidebook for designing interactive distance learning for lecturers, considering that lecturers need guidance on how to design a learning implementation process that remains interactive in a full online learning system during the Covid 19 pandemic. The development of a guidebook stage adopted the model of Dick \& Carey which modified into 4 stages, namely stages; (1) requirement analysis; (2) product design; (3) validation and evaluation; and (4) product revision. Based on development result, data found as follows; (1) the expert's assessment shows that the guidebook is included in the criteria of "very good" from the media aspect $(94.44 \%)$ and "good" from the material aspect $(86.11 \%)$ hence the guidebook can be used in learning; (2) test results on a small group shows that the product developed include in the criteria of "good" $(83,33 \%)$ hence the guidebook can be used in learning; (3) field test result that the product developed include in the criteria of "good" $(89,28 \%)$ hence the guidebook can be used in learning.
\end{abstract}

Key words: Interactive learning, distance learning

\begin{abstract}
ABSTRAK
Tujuan penelitian ini untuk mengembangkan buku panduan merancang pembelajaran interaktif jarak jauh (PIJAR) bagi dosen, mengingat dosen memerlukan panduan bagaimana merancang proses pelaksanaan pembelajaran yang tetap interaktif pada sistem pembelajaran full dalam jaringan (daring) selama masa pandemi Covid 19. Pengembangan buku panduan menggunakan adaptasi model Dick and Carey dalam empat tahap yaitu (1) analisis kebutuhan); (2) desain produk; (3) validasi dan evaluasi; dan (4) revisi produk. Berdasarkan hasil pengembangan diperoleh data sebagai berikut; (1) penilaian dari ahli menunjukkan bahwa buku panduan termasuk dalam kriteria "sangat baik" dari aspek media $(94,44 \%)$ dan "baik" dari aspek materi $(86,11 \%)$ sehingga buku panduan dapat digunakan dalam pembelajaran; 2 ) hasil uji coba kelompok kecil menunjukkan bahwa produk yang dikembangkan termasuk dalam kriteria "baik" (83,33\%) sehingga buku panduan dapat digunakan dalam pembelajaran; dan 3) hasil uji coba lapangan menunjukkan bahwa produk yang dikembangkan termasuk dalam kriteria "baik" $(89,28 \%)$ sehingga buku panduan dapat digunakan dalam pembelajaran.
\end{abstract}

Kata kunci: Pembelajaran interaktif, pembelajaran jarak jauh

\section{PENDAHULUAN}

Pembelajaran sistem dalam jaringan (daring) dengan tipe full daring menjadi keniscayaan penerapannya di Indonesia selama masa pandemi Covid 19 mewabah. Saat ini, sistem ini dianggap tepat untuk diterapkan mengingat potensi penularan virus covid 19 akan lebih tinggi bila pembelajaran di satuan pendidikan dilakukan secara tatap muka langsung. Pembelajaran daring merupakan pembelajaran yang menggunakan jaringan internet dengan aksesibilitas, konektifitas, dan kemampuan untuk memunculkan berbagai jenis interaksi pembelajaran (Moore, DicksonDeane, \& Galyen., 2011). Dengan demikian para pelaku pendidikan harus gerak cepat untuk beradaptasi dan berinovasi pada perubahan sistem pembelajaran ini, termasuk bagi para dosen. Diyakini bahwa dosen adalah pendidik professional yang memiliki sikap terbuka akan hal-hal baru, baik pada aspek pedagogis maupun teknologi pendidikan yang sarat di dalam sistem pembelajaran full daring.

Sesuai arahan Menteri Pendidikan dan Kebudayaan (Mendikbud) melalui Surat Edaran Mendikbud Nomor 4 Tahun 2020 agar peserta didik belajar dari rumah melalui pembelajaran jarak jauh dan arahan dari Universitas Palangka Raya dengan SE Rektor Nomor 1140/un24/II/2020 mengenai panduan umum penyelenggaraan kegiatan akademik dalam tatanan normal baru Universitas Palangka Raya, Jurusan Pendidikan Teknlogi dan Kejuruan (PTK) akan menyelenggarakan Pembelajaran Jarak Jauh secara 
penuh dengan mengoptimalkan platform daring. Selain menjalankan arahan dari institusi, payung hukum penyelenggaraan Pembelajaran Jarak Jauh (PJ) dilakukan berdasar tiga pertimbangan berikut ini; (1) PJJ diselenggarakan sebagai bentuk dukungan pada pemutusan penyebaran COVID-19 yang saat ini sedang diupayakan bersama secara global. Dengan PJJ diharapkan dapat meminimalisasi interaksi fisik yang berimplikasi pada meningkatnya resiko penularan virus; (2) PJJ diselenggarakan sebagai bentuk pelaksanaan new normal, yaitu kondisi pasca COVID-19 yang menuntut perubahan-perubahan mendasar pada pola interaksi dan operasional di berbagai bidang, termasuk bidang pendidikan. PJJ menjadi langkah awal proses adaptasi secara cepat untuk menyambut tata kehidupan baru, terutama tata pendidikan yang baru; dan (3) UPR melalui Pusat TIK dan LP3MP tengah menyiapkan proses transformasi digital. Penyelenggaraan PJJ diharapkan menjadi akselerator untuk mencapai hal tersebut. PJJ yang akan dilaksanakan semasa pandemi COVID-19 diharapkan dapat memberikan pengalaman baru bagi civitas akademika, baik dosen, mahasiswa, maupun tenaga kependidikan, untuk lebih siap menghadapi transformasi yang berkelanjutan.

Mengutip pernyataan seorang pemerhati pendidikan yang menyatakan bahwa jangan sampai PJJ kehilangan makna pembelajaran, kehilangan interaksi. (Interaksi maksudnya) Bukan hanya siswa dengan materi tapi juga peserta didik dengan pendidik. Jika tidak ada interaksi pembelajaran jarak jauh, hanya tertinggal jarak jauhnya saja tidak ada pembelajaran (Sandi B.I, 2020). Dengan demikian PJJ yang interaktif adalah suatu bentuk pendekatan penyelenggaraan yang patut dilaksanakan selama pandemi COVID-19.

Berinteraksi dengan orang lain dapat meningkatkan berbagai manfaat penting termasuk kesejahteraan, produktivitas dan pencapaian kelompok (Arena, Pentland \& Price, 2010; Barsade \& Gibson, 2012; de Gelder \& Hortensius, 2014; Yano, 2013). Memahami proses yang mendasari pembelajaran sosial dapat membantu dalam merancang kesempatan belajar yang memanfaatkan keinginan bawaan manusia untuk berinteraksi secara sosial. Mengingat manfaat dari interaksi tersebut maka pembelajaran yang interaktif perlu diupayakan keberlangsunganya di dalam kelas pembelajaran full daring.

PJJ yang interaktif adalah implementasi model pembelajaran yang memungkinkan mahasiswa berinteraksi dengan dosen, teman sekelas dan media pembelajaran. Untuk itu pembelajaran interaktif sangat bermanfaat dan membantu dalam menghidupkan kelas full daring. Karena selama pembelajaran, interaksi dan komunikasi antar sesama mahasiswa dan dosen tetap terjaga. Sehingga menghindari pembelajaran yang bersifat monoton. Guna mengoptimalisasi efektifitas proses pembelajaran jarak jauh (Hasibuan \& Damanik,
2020). Jenis model desain pemelajaran seperti Blended learning, Flipped Learning, sinkron dan asinkron, pembelajaran kelompok dan individual (Chaeruman, 2013) adalah model desain pembelajaran interaktif jarak jauh yang dapat dipertimbngkan untuk digunakan. Semua model desain pembelajaran tersebut perlu dipadukan dengan alur pembelajaan, ragam metode sinkron \& asinkron, dan ragam platform media pembelajaran agar efektif mencapai tujuan pembelajaran.

Strategi pembelajaran yang dapat dilakukan dosen agar pembelajaran yang interaktif antara lain adalah; (1) Temukan cara untuk menumbuhkan interaktivitas sosial dari pengalaman belajar mahasiswa dengan teman sebaya yang beragam; (2) eksplorasi cara untuk memfasilitasi budaya kelas yang dapat menumbuhkan makna, nilai, dan keyakinan bersama di antara mahasiswa, dan dianggap sebagai lingkungan yang aman dan nyaman bagi mahasiswa untuk berinteraksi dan berkolaborasi; (3) eksplorasi bagaimana penggunakaan teknologi pendidikan dan kemudian menilai dampaknya apakah menguntungkan atau tidak menguntungkan pada dinamika sosial pembelajaran (Nugent A., et al., 2019). Dalam kaitanya pada pelaksaaan pembelajaran jarak jauh maka dosen berperan penting dalam mewujudkan iklim pembelajaran di kelas full daring yang interaktif namun tetap efektif. dengan demikian para dosen dituntun agar selalu dapat menghadirkan strategi pembelajaran yang tepat di kelas full daring.

Pengalaman pelaksanaan PJJ di Jurusan PTK semester genap Tahun Ajaran 2019/2020 yang lalu ditemui salah satu permasalahan yaitu kurangnya keaktifan mahasiswa selama mengikuti pembelajaran jarak jauh. Sebagai upaya mengatasi permasalahan tersebut diperlukan penyelenggaraan PJJ yang interaktif atau yang bisa disebut dengan istilah Pembelajaran Interaktif Jarak Jauh atau disingkat menjadi PIJAR. Konsep dan prinsip pelaksanaan PIJAR adalah dengan memperhatikan interaksi, partisipasi dan keaktifan peserta didik agar suasana pembelajaran berpusat pada peserta didik sehingga timbul pembelajaran yang bermakna. Agar memiliki kesamaan konsep dan prinsip dalam merancang dan melaksanaan pembelajaran jauh yang interaktif diantara para dosen maka diperlukan semacam buku panduan yang layak digunakan dalam pembelajaran jarak jauh. Berdasarkan latar belakang masalah ini maka peneliti bermaksud mengadakan penelitian pengembangan buku panduan merancang pembelajaran interaktif jarak jauh (PIJAR) bagi dosen jurusan PTK.

\section{METODE}

Penelitian pengembangan merupakan jenis metode penelitian yang digunakan dalam penelitian ini. Model penelitian pengembangan menggunakan adaptasi dari model Dick and Carey yang diimplementasikan sampai 
4 tahapan. Tahapan yang dimaksud yaitu; 1) analisis kebutuhan; 2) desain produk; 3) validasi dan evaluasi; 4) revisi. Keempat tahapan tersebut dilaksanakan secara sistematis setahap demi tahap.

Instrumen yang digunakan berupa angket penilaian semi tertutup, dimana responden dapat memilih opsi jawaban yang tersedia serta dapat memberikan jawaban lain dengan menuliskannya pada tempat yang tersedia. Responden terdiri atas ahli materi, ahli media, dan dosen yang berstatus aktif sebagai pengampu mata kuliah. Validasi ahli akan dilakukan sebelum produk diujicobakan kepada pengguna. Hal ini dilakukan untuk memperolah masukan berupa kritik dan saran demi peningkatan kualitas produk yang dihasilkan. Angket kepada ahli materi berisi tinjauan tentang penyusunan buku panduan dilihat dari kesesuaian materi/isi dengan tujuan penyusunan buku panduan dan cakupan materi/isi buku panduan. Angket untuk ahli media pembelajaran berisi tinjauan penyusunan buku panduan berdasarkan aspek penggunaan bahasa, tata tulis, tata letak dan gafis. Angket untuk dosen pengampu mata kuliah berisi tinjauan tentang penggunaan buku panduan dilihat dari aspek materi, media dan kepraktisan (user friendly).

Teknik analisis data yang digunakan pada penelitian ini adalah analisis deskriptif. Data hasil angket penilaian dari responden selanjutnya akan dilakukan pembobotan dengan cara memberi skor $1 \mathrm{~s} / \mathrm{d} 4$. Skor akan dikonversi ke dalam 4 kategori untuk mengetahui kelayakan buku panduan yang dikembangkan. Acuan konversi skor menjadi 4 kategori dapat dilihat pada Tabel 1. Nilai kelayakan produk buku panduan dalam penelitian ini akan ditentukan dengan kriteria minimal "cukup" Sehingga, jika hasil angket penilaian dari responden menunjukkan hasil akhir minimal "cukup" maka produk pengembangan buku panduan dinyatakan layak digunakan dengan revisi.

Tabel 1. Kriteria Dekripsi Data

\begin{tabular}{ccc}
\hline Tingkat Pencapaian & Kriteria & Keputusan \\
\hline $90-100$ & Sangat baik & Tidak perlu revisi \\
$75-89$ & Baik & Tidak perlu revisi \\
$65-74$ & Cukup & Direvisi \\
$\leq 64$ & Kurang & Direvisi \\
\hline
\end{tabular}

\section{HASIL PENELITIAN DAN PEMBAHASAN}

Hasil Analisis Kebutuhan

Analisis kebutuhan buku panduan dilakukan dengan menelaah tujuan yang hendak dicapai dan digunakan sebagai acuan dalam menentukan jumlah dan cakupan materi/ isi yang dibutuhkan untuk mencapai tujuan tersebut. Aanalisis tujuan didasarkan pada kajian teori yang relevan dengan pembelajaran interaktif jarak jauh. Hasil analisis kebutuhan terhadap buku panduan merancang pembelajaran interaktif jarak jauh ditunjukkan pada tabel 2 .

Tabel 2. Hasil Analisis Kebutuhan Buku Panduan

\begin{tabular}{|c|c|c|c|}
\hline No. & Tujuan & Materi/ Isi & Rincian Materi/ Isi \\
\hline 1 & $\begin{array}{l}\text { Memahami Konsep Arah } \\
\text { Pembelajaran Jarak Jauh }\end{array}$ & Pendahuluan & $\begin{array}{l}\text { Latar Belakang } \\
\text { Tujuan Penulisan Buku Panduan } \\
\text { Pengertian PIJAR } \\
\text { Tujuan PIJAR } \\
\text { Paradigma PIJAR }\end{array}$ \\
\hline 2 & Merancang PIJAR & Rancangan PIJAR & $\begin{array}{cl}\text { Rancangan umum PIJAR } \\
-\quad \text { Perencanaan Perkuliahan } \\
-\quad \text { Pelaksanaan Perkuliahan } \\
\text { - } \quad \text { Evaluasi Perkuliahan } \\
\text { Pengembangan desain pembelajara PIJAR } \\
\text { - } \quad \text { Blended Learning dan Flipped Learning } \\
-\quad \text { Sinkron dan Asinkron } \\
\text { - } \quad \text { Pembelajaran Individual dan Kelompok } \\
\text { Pengembangan media pembelajaran pada PIJAR } \\
\text { - } \quad \text { Teknik dan Pemilihn Media } \\
\text { - } \quad \text { Pengembangan Konten } \\
\text { Pengembangan evaluasi/ penilaian } \\
\text { - } \quad \text { Model Evaluasi } \\
\text { - } \quad \text { Instrumen Evaluasi }\end{array}$ \\
\hline
\end{tabular}




\begin{tabular}{|c|c|c|c|}
\hline 3 & $\begin{array}{l}\text { Mengimplementasikan } \\
\text { PIJAR }\end{array}$ & Implementasi PIJAR & $\begin{array}{l}\text { Ruang Belajar dan Aktivitas dalam PIJAR } \\
\text { Komunikasi dan Engagement } \\
\text { Model Alur Pembelajaran dalam PIJAR }\end{array}$ \\
\hline 4 & $\begin{array}{l}\text { Memahami Ragam } \\
\text { Metode Pembelajaran } \\
\text { dalam PIJAR }\end{array}$ & $\begin{array}{l}\text { Ragam Metode } \\
\text { Pembelajaran dalam PIJAR }\end{array}$ & $\begin{array}{l}\text { Sinkron/ Sinkronus } \\
\text { Asinkron/Asinkronus }\end{array}$ \\
\hline 5 & $\begin{array}{l}\text { Memahami Ragam } \\
\text { Platform PWembelajaran } \\
\text { dalam PIJAR }\end{array}$ & $\begin{array}{l}\text { Ragam Platform } \\
\text { pembelajaran dalam PIJAR }\end{array}$ & $\begin{array}{l}\text { Ragam Learning Management System (LMS) } \\
\text { Ragam Video Conference } \\
\text { Ragam Aplikasi Chat }\end{array}$ \\
\hline
\end{tabular}

Hasil Desain Produk

Tahap desain produk menghasilkan sebuah prototipe yang kemudian diperbaiki atas saran dari validator ahli materi dan media sehingga hasil akhir buku panduan terwujud. Produk akhir memiliki spesisikasi antaralain sebagai berikut: 1) versi elektronik tesimpan dalam file .pdf dan; 2) ukuran sebesar 6,4 megabyte (MB); 3) versi non elektronik dapat dicetak pada ukuruan kertas A4 (21 x 29,7 cm) dengan berat kertas sekitar 6.600 gram. Tampilan berikut adalah beberapa capture dari desain produk buku panduan versi elektronik.

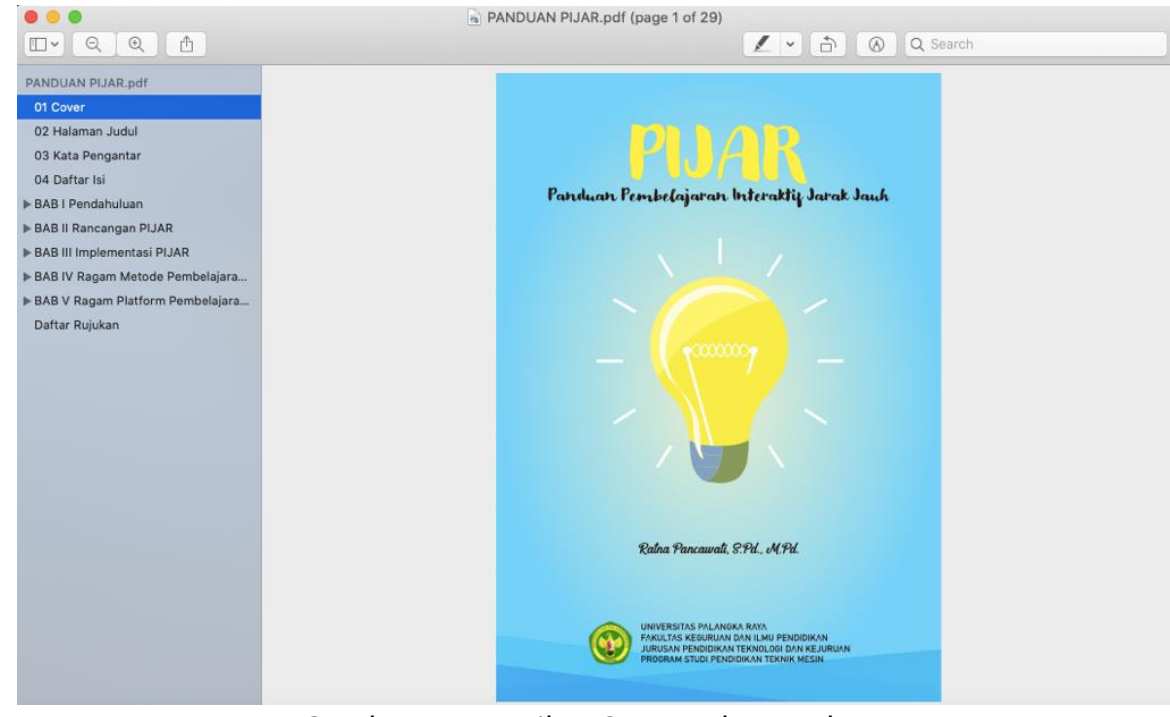

Gambar 1. Tampilan Cover Buku Panduan

Cover buku memuat identitas buku panduan dan menu yang berisi materi/isi dan sub materi dari identitas pengembang. Sisi kiri dapat ditampilkan bar keseluruhan buku panduan.

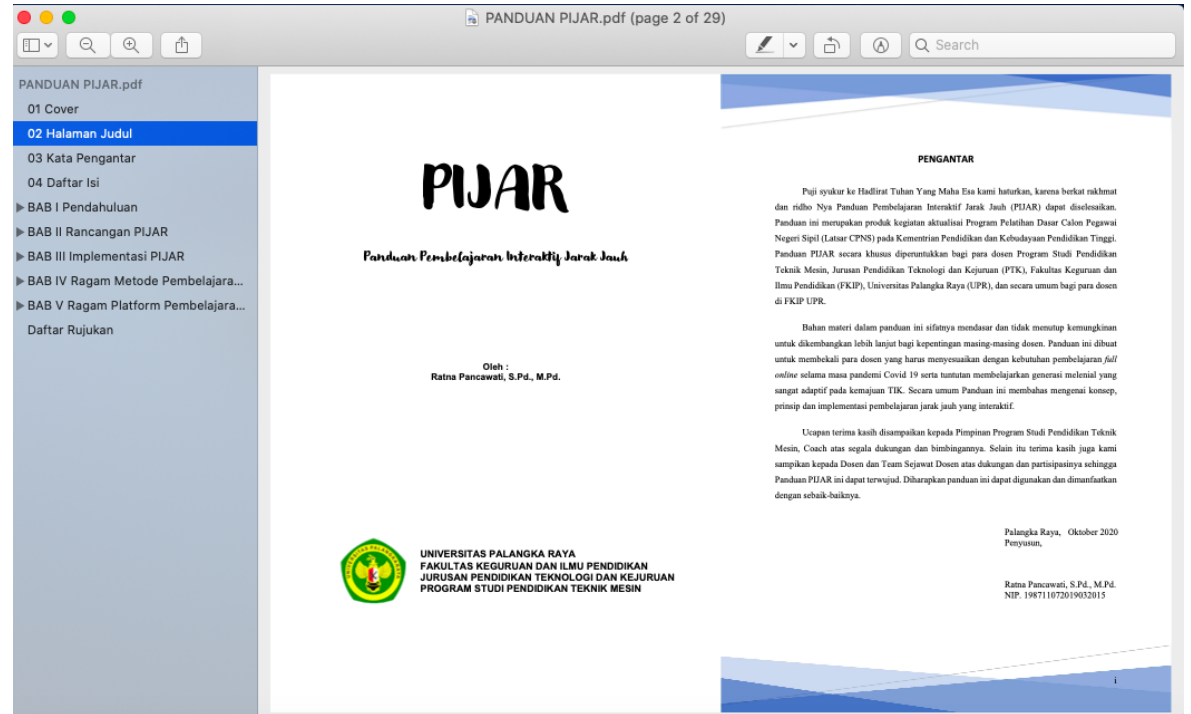

Gambar 2. Tampilan Halaman Depan 
Halaman depan buku panduan menampilkan identitas buku dan kata pengantar dari pengembang. Selanjutnya jika ingin melihat materi atau isi maka pengguna dapat memilih menu bar yang terletak disamping kiri. Misalnya hendak melihat materi mengenai Implementasi PIJAR maka dapat melakukan klik menu "Implementasi PIJAR" dan akan tersaji tampilan sebagai berikut.

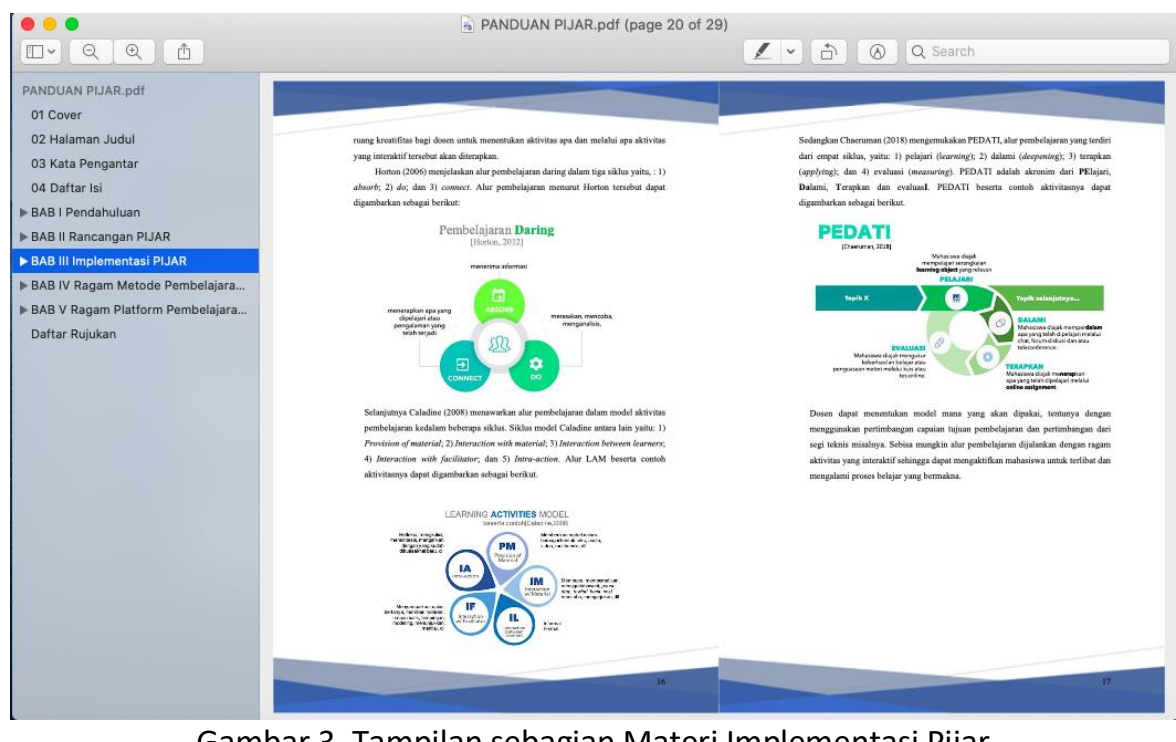

Gambar 3. Tampilan sebagian Materi Implementasi Pijar

Demikian halnya yang perlu dilakukan oleh pengguna, jika hendak membaca materi lain yang ada di dalam buku panduan sesuai yang dikehendaki. Berikut ini disajikan tampilan sebagaian isi materi tentang Ragam Platform Pembelajaran dalam PIJAR.

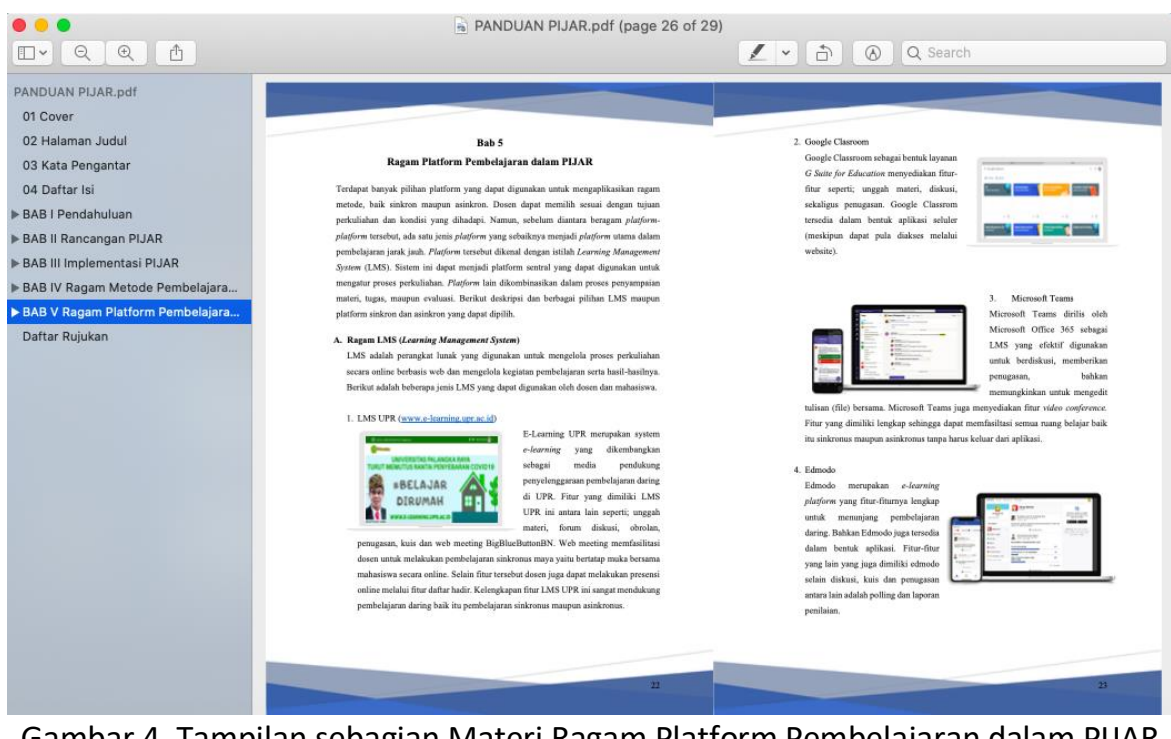

Apabila pengguna hendak membca materi isi buku panduan PIJAR secara urut dan sistematis maka hal yang perlu dilakukan adalah scrooling halaman dari atas ke bawah. File buku panduan ini fleksible dapat dibuka tanpa memerlukan koneksi internet. Selain itu file buku panduan ini dapat dibuka pada berbagai perangkat seperti gawai/ smartphone, notebook, laptop atau perangkat komputer.

\section{Hasil Analisis Data} Validasi Ahli Materi

Tabel 3. Data Validasi Ahli Materi

\begin{tabular}{ccc}
\hline Validator $(\mathrm{n})$ & Skor Total $(\mathbf{E})$ & Skor Maksimal (N) \\
\hline $\mathrm{A}$ & 31 & 36 \\
\hline
\end{tabular}




$$
\begin{gathered}
\text { Persentase }=\frac{\mathbf{\Sigma} \boldsymbol{n}}{\boldsymbol{N}} \boldsymbol{x} \mathbf{1 0 0} \% \\
\text { Persentase }=\frac{\mathbf{3 1}}{\mathbf{3 6}} \boldsymbol{x} \mathbf{1 0 0} \% \\
\text { Persentase }=\mathbf{8 6}, \mathbf{1 1} \%
\end{gathered}
$$

Berdasarkan analisis yang dilakukan diperoleh nilai akhir kelayakan buku panduan sebesar $86,11 \%$. Penilaian mengguanakan 9 kriteria dengan skor tertinggi adalah 4. Kelayakan buku panduan dari aspek materi menunjukkan bahwa buku panduan PIJAR yang dikembangkan tergolong dalam kriteria baik/ layak digunakan pada pembelajaran dan tanpa revisi.

\section{Validasi Ahli Media}

Tabel 4. Data Validasi Ahli Media

\begin{tabular}{ccc}
\hline Validator $(\mathbf{n})$ & Skor Total $(\mathbf{\Sigma})$ & Skor Maksimal $(\mathbf{N})$ \\
\hline $\mathrm{B}$ & 34 & 36 \\
\hline & Persentase $=\frac{\mathbf{\Sigma} \boldsymbol{n}}{\boldsymbol{N}} \boldsymbol{x} \mathbf{1 0 0} \%$ \\
& Persentase $=\frac{\mathbf{3 4}}{\mathbf{3 6}} \boldsymbol{x} \mathbf{1 0 0} \%$ \\
Persentase & $=\mathbf{9 4 , 4 4 \%}$
\end{tabular}

Berdasarkan analisis yang dilakukan diperoleh nilai akhir kelayakan buku panduan sebesar 94,44\%. Penilaian mengguanakan 9 kriteria dengan skor tertinggi adalah 4. Kelayakan buku panduan dari aspek media menunjukkan bahwa buku panduan PIJAR yang dikembangkan tergolong dalam kriteria sangat baik/ layak digunakan pada pembelajaran dan tanpa revisi.

\section{Uji Coba Kelompok Kecil}

Uji coba kelompok kecil dilakukan terhadap 3 responden yaitu dosen jurusan Pendidikan Teknologi dan Kejuruan (PTK), yang terdiri dari 2 orang dosen program studi Pendidikan Teknik Mesin dan 1 orang dosen program studi Pendidikan Teknik Bangunan.

Tabel 5. Data Uji Coba Kelompok Kecil

\begin{tabular}{ccc}
\hline Dosen (n) & Skor Total ( $)$ & Skor Maksimal (N) \\
\hline A & 30 & 40 \\
B & 34 & 40 \\
C & 36 & 40 \\
\hline
\end{tabular}

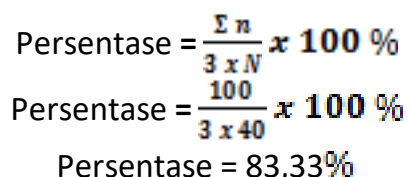

Diperoleh nilai akhir kelayakan buku panduan sebesar 83,33\%. Penilaian mengguanakan 10 kriteria dengan skor tertinggi adalah 4 . Kelayakan buku panduan dari aspek materi, media dan kepraktisan menunjukkan bahwa buku panduan PIJAR yang dikembangkan tergolong dalam kriteria baik/ layak digunakan pada pembelajaran dan tanpa revisi.

\section{Uji Coba Lapangan}

Uji coba kelompok kecil dilakukan terhadap 3 responden yaitu dosen jurusan PTK, yang terdiri dari 5 orang dosen program studi Pendidikan Teknik Mesin dan 2 orang dosen program studi Pendidikan Teknik Bangunan.

Tabel 6. Data Uji Coba Lapangan

\begin{tabular}{ccc}
\hline Dosen (n) & Skor Total ( $)$ & Skor Maksimal (N) \\
\hline A & 34 & 40 \\
B & 31 & 40 \\
C & 40 & 40 \\
D & 33 & 40
\end{tabular}




$\begin{array}{lll}E & 40 & 40 \\ F & 39 & 40 \\ G & 33 & 40\end{array}$

$$
\begin{gathered}
\text { Persentase }=\frac{\Sigma n}{3 \times \mathbb{N}} \boldsymbol{x} \mathbf{1 0 0} \% \\
\text { Persentase }=\frac{250}{7 \times 40} \boldsymbol{x} \mathbf{1 0 0} \% \\
\text { Persentase }=89,28 \%
\end{gathered}
$$

Diperoleh nilai akhir kelayakan buku panduan sebesar $89,28 \%$. Penilaian mengguanakan 10 kriteria dengan skor tertinggi adalah 4. Kelayakan buku panduan dari aspek materi, media dan kepraktisan menunjukkan bahwa buku panduan PIJAR yang dikembangkan tergolong dalam kriteria baik/ layak digunakan pada pembelajaran dan tanpa revisi. Adapun komentar- komentar yang berupa saran dari para responden dipertimbngkan oleh pengembang untuk menyempurnakan produk buku panduan agar semakin baik performanya.

Berdasarkan data yang telah disajikan sebelumnya, maka ringkasan data hasil pengembangan dapat

\begin{tabular}{|c|c|c|c|}
\hline No. & Data & Persentase & Kriteria dan Keputusan \\
\hline 1 & Ahli Materi & $86,11 \%$ & Baik/ layak digunakan dalam pembelajaran dan tidak perlu revisi \\
\hline 2 & Ahli Media & $94,44 \%$ & $\begin{array}{l}\text { Sangat baik/ sangat layak digunakan dalam pembelajaran dan } \\
\text { tidak perlu revisi }\end{array}$ \\
\hline 3 & Uji Coba Kelompok Kecil & $83,33 \%$ & Baik/ layak digunakan dalam pembelajaran dan tidak perlu revisi \\
\hline 4 & Uji Coba Lapangan & $89,28 \%$ & Baik/ layak digunakan dalam pembelajaran dan tidak perlu revisi \\
\hline
\end{tabular}
ditampilkan pada Tabel 7 berikut.

Tabel 7 Ringkasan Data Hasil Pengembangan

Dengan demikian secara keseluruhan produk akhir buku panduan PIJAR dinyatakan layak dari aspek materi, media dan kepraktisan sehinga dapat digunakan oleh para dosen jurusan PTK, Fakultas Keguruan dan Ilmu Pendidikan, Universitas Palangka Raya dalam menyelenggarakan pembelajaran jarak jauh. Khususnya bagi dosen yang hendak menghidupkan kembali suasana/ ilkim kelas menjadi lebih interaktif baik itu antar dosen dengan mahasiswa, antar mahasiswa dengan mahasiswa, maupun antar mahasiswa dengan sumber belajar, metode dan media belajar.

\section{KESIMPULAN DAN SARAN}

Hal penting yang dapat disimpulkan pada penelitian ini adalah; 1) penilaian dari para ahli menunjukkan bahwa buku panduan PIJAR "sangat baik" dari aspek media (94,44\%) dan "baik" dari aspek materi (86,11\%) sehingga buku panduan dapat digunakan pada pembelajaran jarak jauh; 2) hasil uji coba kelompok kecil menunjukkan bahwa produk yang dikembangkan termasuk dalam kriteria "baik" (83,33\%) sehingga buku panduan PIJAR dapat digunakan pada pembelajaran jarak jauh; 3) selanjutnya hasil uji coba lapangan menunjukkan bahwa produk yang dikembangkan termasuk dalam kriteria "baik" $(89,28 \%)$ sehingga buku panduan PIJAR dapat digunakan dalam pembelajaran jarak jauh.
Saran bagi penelitian selanjutnya dalam rangka penyempurnaan buku panduan, agar; 1 ) perkaya lagi model-model pembelajaran interaktif jarak jauh agar dosen memiliki banyak variasi dalam penggunaannya; 2) buku panduan versi non elektronik dicetak lebih banyak, karena keterbatsan pada penelitian ini buku panduan versi cetak sangat terbatas jumlahnya; 3) sebaiknya buku panduan yang dihasilkan didaftarakan ke perrpusnas untuk mendapatkan E-ISSN dan P-ISSN, karena keterbatasan pada penelitian ini buku panduan belum memiliki 2 hal tersebut.

\section{DAFTAR PUSTAKA}

Arena, M, Pentland, A. \& Price, D. (2010). Honest signals: hard measures for social behavior. Organizational Development Journal, 28(3), 11-20.

Barsade, S.G. \& Gibson, D.E. (2012). Group Affect: It's Influence on Individual and Group Outcomes. Current Directions in Psychological Science, 21(2), 119-123. https://doi:10.1177\%2F0963721412438352

Chaeruman, A.U. (2013). Merancang Blended Learning. TEKNODIK: Jurnal Teknologi Pendidikan. DOI: 10.32550/teknodik.v17i4.482. https://doi.org/10.32550/teknodik.v17i4.482

de Gelder, B \& Hortensius, R. (2014). The many faces of the emotional body. In Decety, J. \& Christen, Y. (Eds.). New Frontiers in Social Neuroscience, 
Research and Perspectives in Neurosciences 21, Springer International Publishing Switzerland, pp.153-164. doi: 10.1007/978-3-319-02904-7_4

Hasibuan, S.A \& Damanik, L.A (2020). "Metode Pembelajaran Interaktif yang diselenggarakan secara Daring Akibat Mewabahnya Covid-19", Prossiding Seminar Hasil Penelitian, Universitas Muslim Nusantara (UMN) Al Washliyah, Oktober, Medan.

Moore, J. L., Dickson-Deane, C., \& Galyen, K. (2011). ELearning, online learning, and distance learning environments: Are they the same? Internet and HigherEducation.

https://doi.org/10.1016/jiheduc.2010.10.001

Nugent A., et al. (2019). Higher Education Learning Framework: An evidence informed model for university learning. Brisbane: The University of Queensland.

Yano, K. (2013). The science of human interaction and teaching. Mind, Brain and Education, 7(1), 19-29. doi:10.1111/ mbe.12003 